\title{
Automation for Genomics, Part Two: Sequencers, Microarrays, and Future Trends
}

\author{
Deirdre Meldrum \\ Department of Electrical Engineering, Genomation Laboratory, University of Washington, \\ Seattle, Washington 98195-2500, USA
}

\begin{abstract}
Automation for genomics has enabled a 43-fold increase in the total finished human genomic sequence in the world in the past four years. This is the second half of a two-part, noncomprehensive review that presents an overview of different types of automation equipment used in genome sequencing. The first part of the review, published in the previous issue, focused on automated procedures used to prepare DNA for sequencing or analysis. This second part of the review presents a look at available DNA sequencers and array technology and concludes with a look at future technologies. Alternate sequencing technologies including mass spectrometry, biochips, and single molecule analysis are included in this review.
\end{abstract}

Sequencing data, essential for many of the medical breakthroughs of today and tomorrow, is currently accumulating at an exponential rate, largely because of advances in sequencing methods and laboratory automation. Instruments are available that can automate nearly every step in the large-scale sequencing process.

The first article in this two-part review (Meldrum 2000) presented a description of automation designed for isolating DNA, cloning or amplifying DNA, preparing enzymatic sequencing reactions, and purifying DNA. Part one of the review also showed that the majority of genome centers use both in-house automation and commercial automation (Collins et al. 1998; Wendl et al. 1998; Mullikin and McMurragy 1999; Spurr et al. 1999; see http://www.genome.org for a supplementary table providing a snapshot view of automation used at a number of different genome centers).

In this, the second part of the review, the focus is on automation after DNA preparation and sequencing reactions - on obtaining the sequence and its analysis. A discussion of future technologies for DNA sequencing projects is also included. (See the web sites referenced for photos or further details on the instruments presented.)

\section{Sequencers}

The invention of the automated fluorescence DNA sequencer (Smith et al. 1985; Smith et al. 1986; Hood et al. 1987; Hunkapiller et al. 1991) has advanced the level of DNA sequencing. Until recently, the most commonly used format was a horizontal or vertical slab gel. Years of research on capillary sequencers have yielded several recent commercial systems that significantly increase the throughput and decrease the time

E-MAIL deedee@ee.washington.edu; FAX (206) 221-5264

Article and publication are at www.genome.org/cgi/doi/10.1101/ gr. 157400 . required to sequence. Some of the efforts in slab- and capillary-based methods are described below. A review of automated DNA sequencing operation is provided in Huang (1999).

\section{Slab-Based Sequencers}

The ABI PRISM 377 DNA Sequencer from Applied Biosystems (Foster City, CA) (http://www.appliedbiosystems.com) uses multicolor fluorescence labeling technology and four-dye, one-lane detection (Smith et al. 1985). A charge-coupled device (CCD) camera is used for sequencing rates up to 200 bases per sample per hour. It can run $18,36,64$, or 96 samples simultaneously per vertical gel (Stuebe et al. 2000). Gel plates come in four different lengths to optimize run times and sample resolution.

The automated laser fluorescent (ALF) DNA sequencer, ALFexpress, from Amersham Pharmacia Biotech (Piscataway, NJ) (http://www.apbiotech.com), originally developed by EMBL, uses a single fluorescent-labeled primer that is used in all four sequencing reactions (Ansorge et al. 1987). The resulting fluorescent-labeled DNA strands are separated in four different lanes in the electrophoresis system. A fixed argon laser emits light that passes through the width of the gel and is detected by detectors in each of the 40 lanes (Jandreski 1995).

To achieve higher throughput than current stateof-the-art sequencers, a hyperspectral imaging DNA sequencer called "ASTRAL" has been under development (O'Brien et al. 1998). This system is distinguished from other plate/gel-based systems by the hyperspectral detection system, which can image the entire read area of the gel at once, eliminating the need for a scanning detector; thus, the sequencer has no moving parts. The detection system, which combines a spectrograph and a cooled CCD camera, can detect more than four dyes per lane. Illumination is from the side (Ansorge et al. 
1986; Nemoto 1996), but a beamsplitter divides an argon-ion laser beam in two, sending one half through the left side of the gel and the other through the right side. The ASTRAL is designed to accommodate 96 lanes. A typical experiment takes $7-8 \mathrm{hr}$ to generate $\sim 300$ base read lengths per lane and generates 5000 CCD camera exposures. Initial experiments run with pGEM DNA demonstrate that the ASTRAL can produce results comparable to the Applied Biosystems ABI PRISM 373/377 sequencers. The ASTRAL spectral imaging system uses the same approach used in the ABI PRISM 3700 capillary sequencer. Future experiments will determine the capabilities of the ASTRAL such as read lengths, lane density (throughput), and quality of bases.

The European Molecular Biology Laboratory (EMBL) (Heidelberg, Germany) (http://www.emblheidelberg.de) has a longstanding history in sequencing (Ansorge et al. 1986, 1987). The EMBL ARAKIS sequencer is a multiple laser and dye system with a throughput of up to $1 \mathrm{Mb}$ of sequence per day (J. Zimmermann, pers. comm.). The ARAKIS sequencing system takes advantage of the DOUBLEX technique developed at EMBL (Voss et al. 1997) that allows the simultaneous online sequencing of two DNA strands of a double-stranded template in a single sequencing reaction with two different primers, each labeled with a different fluorescent dye. Simultaneous sequencing is also possible from one reaction with the use of two unlabeled primers and internal labeling by two dNTPs labeled with different dyes. Because the sequences of both strands of the template are determined simultaneously, the costs of labor, DNA template preparation, sequencing reactions, and gel casting are halved. A QUADRUPLEX system that uses four lasers and dyes and has a potential throughput of 4000 bases in a single sequencing reaction has been developed (Ansorge 1997). In Stegemann et al. (1999) it is reported that the ARAKIS simultaneously sequenced five different DNA templates for a yield of 5000 bases in a single sequencing reaction. It may also be possible to increase the number of lasers and dyes to eight or more, thereby substantially increasing the throughput and decreasing the costs of sequencing. EMBL has produced ARAKIS systems and transferred them to J. Weissenbach (Genoscope, Paris) and S. Paabo (Genome Centre, Munich) for their large-scale sequencing operations.

The LI-COR, Inc. (Lincoln, NE) (http://www. licor.com) Model $4200\left(\mathrm{IR}^{2}\right)$ automated DNA sequencer, launched in 1997, is a two-dye near-infrared DNA analysis system. It can detect the products of two different sequencing reactions in parallel enabling pooling reactions and simultaneous bidirectional sequencing (SBS). Sequencing both directions on a template by combining forward and reverse primers in the same direction produces twice the data from each reaction prepared. The 4200 has 64 lanes and can produce read lengths of 1000 bases from each end of the template with $99 \%$ accuracy or 60 bases in under $3 \mathrm{hr}$. To reduce preparation time, the Stratagene (La Jolla, CA) (http://www.stratagene.com) CastAway pre-cast, disposable gels may be used in the 4200. In November 1999, LI-COR became the exclusive contract manufacturer of NEN Life Science Products, Inc. (Boston, MA) NEN Global IR ${ }^{2}$ DNA sequencer and NEN Global IR ${ }^{2}$ DNA Analyzer. This is an enhancement of the $4200 \mathrm{IR}^{2}$ system with e-Seq Software, IRDye 800 terminators, and the Global IR ${ }^{2}$ System that add new software and networking options including Internet connectivity.

In 1998, MJ Research Inc. (Waltham, MA) (http:// www.mjr.com) obtained their first horizontal ultrathin gel electrophoresis (HUGE) system called the BaseStation from GeneSys Technologies, Inc. (Sauk City, WI). A product based on the design by J. Luckey and R. Brumley of GeneSys (Kostichka et al. 1992) was launched in early 2000. The system includes an eightchannel robot well loader with a minimum volume of $3 \mu \mathrm{L}$, so no manual loading is required. A $75-\mu \mathrm{m}$ thin polyacrylamide gel is used to run 96 lanes in three plate-length formats. A short plate can give 450 bases in $<90 \mathrm{~min}$, whereas the longest plate can produce $>1000$ bases in five hours. The system can accommodate various chemistries using the replaceable filter set for detection. The detection sensitivity is $\sim 10$ attomoles, making it the most sensitive sequencing instrument on the market. Future plans include a 192lane system with easy gel pouring and disposable plates for unattended operation (P. Vander Horn, pers. comm.).

At the University of Wisconsin (Madison, WI), Dr. Lloyd Smith and his group developed a DNA sequencer with vertical slab gels to accommodate 125 lanes per gel with read lengths of $>800$ base pairs in 18-hr run times. These sequencers were hardened in the context of the sequencing to Bermuda quality standards of a megabase region of human chromosome 19 (L. Smith and M. Westphall, pers. comm., Yin et al. 1996).

Visible Genetics Inc. (Toronto, ON, Canada) (http://www.visgen.com) first introduced the OpenGene sequencer in 1996 with 30-min electrophoresis times for 400 bases and a disposable gel cassette. In 1999, the MicroGene Clipper two-dye automated DNA sequencer (Yager et al. 1999) was introduced with a $50-\mu \mathrm{m}$ ultrathin sequencing gel in a disposable MicroCel cassette. With a Gel Toaster system, the MicroCel cassette can be cast, prepared, and polymerized in $<5$ min. The Clipper sequencer throughput can be doubled by running two samples simultaneously in the same lane for a maximum of eight samples per sequencing run. The two-dye Long-Read Tower Sequencer can produce 400 bases in 30 min with the 
MicroCel cassette or 1000 bases in $<4 \mathrm{hr}$ with a LongRead MicroCel.

\section{Capillary-Based Sequencers}

Multiple capillary array sequencers are being developed by a number of investigators (e.g., J.Z. Zhang et al. 1995, 1999; Bashkin et al. 1996a,b; Carrilho et al. 1996; Cohen and Karger 1987; Cohen et al. 1987; Kheterpal et al. 1996; Dovichi 1997, 1999; Kheterpal and Mathies 1999; Pang et al. 1999; Crabtree et al. 2000; Gao and Yeung 2000; McWhorter and Soper 2000) to provide high throughput analysis of DNA fragments.

The Beckman Coulter, Inc. (Fullerton, CA) (http:// www.beckmancoulter.com) CEQ 2000 is an eightcapillary DNA sequencer that automatically pours the gel and denatures and loads the samples. It can process eight samples read to 500 bases in 2 hr or 96 samples automatically in $24 \mathrm{hr}$. It uses four-color fluorescence detection with diode laser excitation in the red region using proprietary WellRED dyes (Evans 2000).

At the Max-Planck-Institute for Molecular Genetics (MPIMG) in Berlin, a multicapillary electrophoresis (MCE) device has been developed for DNA analysis (http://www.mpimg-berlin-dahlem.mpg.de/ heller; C. Heller, pers. comm.). The system has 96 capillaries and can process up to 40 microplates (96-well or 384-well) without human intervention for a throughput of 15,000 samples before it has to be reloaded. The features of the sequencer include a plate stacker, autosampler, 96 capillaries of 58-cm length, platinum electrodes, excitation with a $60-\mathrm{mW}$ argon-ion laser, detection with a CCD camera and imaging spectrograph, true parallel "on-capillary" detection with no moving parts, a low viscosity separation matrix developed inhouse, and compatibility with existing biochemistry (Behr et al. 1999).

The MegaBACE 1000 by Molecular Dynamics (Sunnyvale, CA) (http://www.mdyn.com), now a division of Amersham Pharmacia Biotech (http://www. apbiotech.com/MegaBACE), is a 96-capillary array fluorescence-based DNA sequencer with interchangeable filter sets, confocal detection, and NT workstation. It automates gel matrix replacement, sample injection, DNA separation, and data analysis; uses a linear polyacrylamide separation matrix; and has a turnaround time of $2 \mathrm{hr}$ per run. Minimal sample loading volume is $5 \mu \mathrm{L}$ and the samples are introduced into the system in a 96-well format. Each run requires $<15$ min of simple operator interaction. The capillaries have a lifetime of $\sim 130$ or more runs and can be run with both dye primer and dye terminator reactions (Bashkin et al. 1996a,b; J. Bashkin, pers. comm.). DYEnamic ET primers and DYEnamic ET terminator kits with Thermo Sequenase DNA polymerse are optimized for use with MegaBACE1000. Read lengths in excess of $800 \mathrm{bp}$ are possible with an average read length with dye primer chemistry of $>550$ bp at $98.5 \%$ accuracy with M13 standard template (Madabhushi et al. 1997; Madabhushi 1998).

The DOE Joint Genome Institute (JGI) (http:// www.jgi.doe.gov) installed 84 production MegaBACEs between May and September 1999. The machines are mounted on four-foot tables with flat screen displays for a high density installation. The machines are currently run 6 times/day, 5 days/week with $\sim 550$ base pair read length and $85 \%$ pass rates sequencing plasmids. The machines have been run up to 9 times per day, 7 days per week (M. Pollard, pers. comm.).

Incyte Pharmaceuticals, Inc. (http://www.incyte. com) runs MegaBACE1000 systems 24 hours a day, seven days a week, to sequence one million reads per month (R. Scott, http://www.incyte.com/webcase/ slides/sld004.htm).

Using experience gained with the ABI PRISM 310 Genetic Analyzer single capillary instrument, Applied Biosystems developed the ABI PRISM 3700 DNA Analyzer with 96 primary capillaries and 8 reserve capillaries. It has a turnaround time of $\sim 2.5 \mathrm{hr}$ for an average read length of 550 base pairs with single base resolution. Samples are automatically loaded from 96- or 384-well microplates by electrokinetic injection into 96 capillaries. At the detection end of the capillaries, the samples flow through a sheath flow cuvette detector (originally developed by Dr. Norman Dovichi, University of Alberta, Edmonton, Canada; http://www. chem.ualberta.ca/faculty/dovichi.htm; Swerdlow et al. 1991; Zhang et al. 1995; Service 1998c) to eliminate capillary wall scattering and to provide continuous excitation and detection. Uncoated capillaries are used and are dynamically coated with a polymer such as POP-6 to control electro-osmotic flow. The system uses two-dimensional CCD imaging and is capable of using five dyes. It has a signal-to-noise ratio that is 10 times better than the Applied Biosystems ABI PRISM 377 sequencer (K. Henessey, pers. comm.). The ABI PRISM 3700 uses four-dye, one-lane simultaneous detection of 96 samples and can run for $24 \mathrm{hr}$ unattended.

Celera Genomics (Rockville, MD) (http://www. celera.com) uses 300 ABI PRISM3700 DNA analyzers to sequence more than one billion bases every month.

The Applied Biosystems ABI PRISM 3100 Genetic Analyzer, based on the ABI PRISM 310 Genetic Analyzer and 3700 DNA Analyzer, was recently introduced to support applications such as comparative sequencing and DNA fragment analysis. It has 16 capillaries, uses either POP-4 or POP-6 as the separation matrix, and can run unattended for $24 \mathrm{hr}$.

RIKEN (Tsukuba and Wako, Japan) (http:// genome.rtc.riken.go.jp/) has developed the RISA (RIKEN Integrated Sequence Analyzer), a 384-capillary sequencer with disposable capillaries and cross-linked acrylamide. The system consists of three parts: CAS, a 
384-capillary assembler; GVT, a gel filling machine; and RISA, a 384-capillary sequencer. The CAS is a stand-alone machine that cuts a capillary to $48 \mathrm{~cm}$ and simultaneously loads the capillaries into a base plate for placement in the sequencer. After aligning the end of each capillary, a detection window is made by burning off the outer coating of the capillaries within a designated area. Each capillary array assembly takes about 30 min. The GVT washes the inner wall of the capillary and pumps gel into the capillary. In the RISA, 384 samples are simultaneously electrokinetically injected and detected by laser fluorescence. (Y. Hayashizaki and G. Chapman, pers. comm., Sasaki et al. 1998).

\section{Online DNA Sequencers}

A couple of online systems have been developed to automate and integrate thermal cycling, purification, loading, and capillary electrophoresis steps. Samples are placed in the loop of an injection valve; amplified inside of a rapid air thermal cycler (Idaho Technology); separated by liquid chromatography; loaded in a continuous, flow-through manner onto a polymer-filled separation capillary; and detected by laser-induced fluorescence (Swerdlow et al. 1997; Xiong et al. 1998).

Another completely integrated and multiplexed online DNA sequencer was demonstrated in Tan and Yeung (1998) to process eight DNA samples from template to called bases. The system, which is scalable to a 96-capillary online system, uses size-exclusion chromatography that couples a microreactor to capillary electrohoresis for DNA sequencing. Cycle-sequencing reactions are performed in a fused-silica capillary, purification occurs in a size-exclusion chromatographic column, and the sample is online injected into a capillary for electrophoresis.

\section{Pyrosequencing}

Pyrosequencing is a novel DNA sequencing method that takes advantage of four enzymes cooperating in a single tube to determine the nucleotide composition of a DNA fragment in real time. Detection is based on the amount of visible light produced by coupling the pyrophosphate that is released during nucleotide incorporation with the enzymes sulfurylase and luciferase. Unincorporated nucleotides are degraded in the reaction mixture by the enzyme apyrase. A fully automated instrument called the PSQ96 System has been developed primarily for SNP analysis by Pyrosequencing AB (Üppsala, Sweden) (http://www.pyrosequencing.com) to perform pyrosequencing. It uses ink-jet technology to dispense submicroliter volumes of the four nucleotides into a single tube coupled with simultaneous detection of all samples by a single CCD unit (Hyman 1988; Ronaghi et al. 1998a,b, 1999; Ahmadian et al. 2000; Andersson et al. 2000; Nordstrom et al. 2000).

\section{Bioinformatics}

This review does not cover bioinformatics per se, but it is important to mention the software tools developed by Dr. Phil Green for sequence analysis. If it is not possible to ultimately obtain the information we are interested in, the instruments themselves are useless. The PHRED/PHRAP/CONSED software tools, developed under a NIH National Human Genome Research Institute (NHGRI) grant to Dr. Green, have received recognition and use in the worldwide genome community. PHRED reads DNA sequencer trace data, calls bases, assigns quality values (log-transformed error probabilities) to the bases, and writes the base calls and quality values to output files (Ewing and Green 1998; Ewing et al. 1998). PHRED can read trace data from SCF files and Applied Biosystems ABI PRISM 373, 377, and 3700 and Molecular Dynamics' MegaBACE sequencer chromatograph files, automatically detecting the file format. After calling bases, PHRED writes the sequences to files in either FASTA or SCF format. Quality values for the bases are written to FASTA format files or PHD files, which can be used by the PHRAP sequence assembly program to increase the accuracy of the assembled sequence (http://www.phrap.org).

PHRAP is a program for assembling shotgun DNA sequence data. It allows the use of entire reads independent of data quality, uses a combination of usersupplied and internally computed data quality information to improve the accuracy of assembly in the presence of repeats, and constructs contig sequence as a mosaic of the highest quality parts of reads. PHRAP is based on SWAT, a program for searching one or more DNA or protein query sequences or query profiles against a sequence database using a fast implementation of the Smith-Waterman-Gotoh algorithm with affine gap penalties, and CrossMatch, a program based on SWAT for comparing any two sets of DNA or protein sequences. Editing or viewing of PHRAP assemblies is possible with the CONSED or PhrapView programs (http://www.phrap.org).

CONSED is a graphical tool for editing Phrap assemblies (Gordon et al. 1998). CONSED and PHRAP are tightly integrated to take advantage of the merits of each so it is recommended that they be used together. CONSED allows the user to edit bases in a sequence guided by error probabilities. It is also able to pick primers and templates for whichever location is specified by the user and it automates the process of choosing reads for finishing (the AUTOFINISH program) (http://www.phrap.org).

\section{Gel Loaders}

For slab gel electrophoresis systems, one of the ongoing bottlenecks has been the gel loading process. Although this is still performed primarily manually, there are several tools that decrease the time and effort 
required. With the availability of capillary sequencers and, on the horizon, microchip sequencers, it may one day be unnecessary to load slab gels.

EMBL has developed a porous membrane comb that simultaneously loads 200 sample lanes (Erfle et al. 1997). The samples are loaded with a Biomek 2000 robot onto the teeth of a comb made of porous material. The comb, with samples, is then manually inserted above the straight edge of the polymerized gel. An applied electric field drives the samples from the comb into the gel. This porous comb loading system may be used on vertical, horizontal, standard, and ultrathin gel systems.

Similarly, MWG Biotech, Inc. (High Point, NC) (http://www.mwgbiotech.com) has automated comb loading with the MWG Comb Load System, for gelbased DNA sequencing systems such as the ABI 377 or the LICOR 4200. Sequencing reactions are spotted onto 64- or 96-lane membrane combs with a robot (such as the MWG Biotech RoboSeq 4200) and then manually inserted into the acrylamide gel on the sequencer. SIGMA-ALDRICH Corp. (St. Louis, Missouri) (http://www.sigma-aldrich.com) recently introduced QuickComb-96, a porous membrane comb for loading ABI PRISM 377 sequencers. Samples are spotted on individual teeth with any multichannel pepettor and the comb is inserted between the sequencer plates. Samples may be stored directly on the comb for up to two weeks or up to six months at $-20^{\circ} \mathrm{C}$.

A variety of syringe-based gel loaders are available for the Applied Biosystems ABI PRISM sequencers: Hamilton Company (Reno, NV) (http://www. hamiltoncomp.com) eight-channel syringes, the Kloehn Company (Las Vegas, NV) (http://ww. kloehn.com) GL-2000 gel loader, Robbins Scientific Corporation's (Sunnyvale, CA) (http://www. robsci.com) EZSwitch adjustable spacing gel loader and FlexTip and SlimTip fixed spacing gel loaders, and the World Precision Instruments, Inc. (Sarasota, FL) (http://www.wpiinc.com) Gel Mate 96.

Sooner Scientific, Inc. (Garvin, OK) (http:www. soonersci.com) has a variety of tips for loading vertical and horizontal sequencing gels including the 96EZLoad System Multi-Channel Pipette and PrismStrip Tips, an eight-strip tip, for Applied Biosystems ABI PRISM 373/377 sequencers.

At the University of Washington a gel loader has been developed to load agarose gels directly from glass capillaries and without prior well formation (Evensen et al. 1999).

A peristaltic pump gel loader has also been developed (Smith and Watson 1993, 1995).

\section{Microarraying}

As more sequence data becomes available, the desire and ability to perform gene expression analysis has grown rapidly with advances in microarraying technology. In the past several years, a variety of instruments have been developed for producing microarrays for gene expression (Service 1998b; Durick et al. 1999; Harris et al. 2000). The main three methods used for creating the arrays are pin-based fluid transfer (Shalon et al. 1996; Schena 1996; Schena et al. 1996; Castellino 1997; DeRisi et al. 1997; Pollack et al. 1999), piezobased ink-jet dispensers (Marshall and Hodgson 1998), and photolithography (Fodor et al. 1991). Some of the instruments and methods available for microarraying are described below. For a review of microarraying methods and technologies, see Schena et al. (1998), Lander (1999), Nelson et al. (1999), Winzeler et al. (1999), Zhang (1999), Lennon (2000), and van Hal et al. (2000).

Affymetrix, Inc. (Santa Clara, CA) (http://www. affymetrix.com) has developed a cartridge that performs multistep nucleic acid processing on multiple samples simultaneously to prepare nucleic acid targets for their GeneChip assays. The cartridge has polycarbonate chambers and channels that use pneumatically actuated valves and porous hydrophobic vents for fluidic control. Fluids are batch processed using bolus flow and thermoelectric coolers are used to control reaction and storage temperatures (Anderson et al. 1998). The Affymetrix GeneChips (Lockhart et al. 1996; Gunderson et al. 1998; Lipshutz et al. 1999; Harrington et al. 2000) are high-density, miniaturized arrays of DNA probes on a silicon solid support. Photolithograhy and solid-phase chemical analysis techniques are used in this light-directed oligomer synthesis approach to chip production (Fodor et al. 1991, 1997; Pease et al. 1994; Lipshutz et al. 1999). Some of the Affymetrix chips are commercially available and have been used, for example, to sequence the HIV PR and RT genes (Jandreski 1995) and for TP53 mutation detection using the p53 GeneChip (Wen et al. 2000). In April 2000, Affymetrix introduced the Human Genome U95 Set of GeneChips that includes a single array with $>12,000$ full-length human sequences and four arrays with 50,000 ESTs.

The GeneChip Instrument System includes a GeneChip fluidics station, a GeneArray Scanner by Hewlett-Packard, a GeneChip Workstation computer, and a GeneChip Hybridization Oven to automate and analyze GeneChip probe arrays. A recent Affymetrix product is the GeneChip GenFlex Tag Array that uses nucleic acid hybridization to parse up to 2000 individual reaction products from complex pooled mixtures. To provide the capability for individual laboratories to prepare and analyze their own microarrays, the Affymetrix 417 Arrayer and 418 Scanner are available through MWG Biotech (Ebersberg, Germany). The arrayer uses a spotted array-making technology referred to as Pin-and-Ring array technology for me- 
chanically aliquotting fluid samples to create arrays on slides.

Genometrix, Inc. (The Woodlands, TX) (http:// www.genometrix.com) pioneered electronic DNA microarrays and has developed electric field-induced detection and hybridization devices such as the VistaExpress array for gene expression studies and VistaMorph microarray for genotyping. The microarray platform is in a 96-well customizable format for medium-density and high-throughput and up to 250 genes/array (Lamture et al. 1994). In September 1999, Genometrix and Motorola, Inc. agreed to a coexclusive rights agreement to use and commercialize proprietary Genometix electronic DNA chip technology.

Hyseq, Inc. (Sunnyvale, CA) (http://www.hyseq. com) and its partner PE Corporation (Norwalk, CT) are developing a complete preparation and analysis system for a variety of assays based upon the Hyseq HyChip, a universal sequencing chip based on sequencing-byhybridization (SBH) technology. The HyChip system uses arrays of a complete set of DNA probes with a target-specific cocktail of labeled probes to identify differences between a reference and test sample. Because all possible probes are present, a single chip may be used for a wide variety of targets.

Vysis, Inc. (Downers Grove, IL) (http://www.vysis. com) has developed GenoSensor, a genomic array system for addressing gene copy number. Extracted DNA is fluorescently labeled and hybridized to a GenoSensor array that is then inserted into a GenoSensor reader to produce an image for analysis and data reporting. Comparative hybridization permits multiple clones of gene targets to be quantitated by analyzing fluorescent color ratios of individual gene targets on the array. The AmpliOnc I array contains $>50$ gene loci that have been reported to be amplified in various human cancers.

A variety of platforms exist for microarrying using primarily pin-based technology. The MicroGrid II from BioRobotics Ltd. (Cambridge, UK) has spotting density programmable in 10- $\mu \mathrm{m}$ steps and supports 1536-well microplates. It can process $>100$ microscope slides and 24 source plates in one automated run. The MicroGrid Pro uses twin 48-pin microarraying tools.

GeneMachines (San Carlos, CA) (http://www. genemachines.com/facts.html) OmniGrid is a highperformance, multi-axis robot that arrays biological samples from standard 96- or 384-well microplates onto substrates such as glass slides or membranes. It will soon support 1536-well microplates (S. HunickeSmith, pers. comm.). The throughput of the OmniGrid is 17,000 spots on 100 slides with 16 pins in $17 \mathrm{hr}$, 34,000 spots on 100 slides with 32 pins in $17 \mathrm{hr}$, or 64,000 spots on 100 slides with 48 pins in $17 \mathrm{hr}$.

Genetix Ltd. (Christchurch, UK) Q Array is a dedicated microarrayer. With a $15 \times 15$ arraying pattern and the Genetix 16-pin microarraying head, a slide can be prepared with 3600 spots per field and up to four fields per slide for a total of 14,400 spots. Higher densities are achieved using pins that print smaller spots. A $25 \times 25$ array gives 10,000 spots per field and up to 40,000 per slide. A 24-pin head is also available and up to 84 slides may be accommodated at one time. The Genetix Q Pick and the Q Bot may also be used for microarraying with a 16-pin head that uses either 0.15$\mu \mathrm{m}$ diameter Genetix solid pins or TeleChem 'Chipmaker' split pins.

Intelligent Bio-Instruments (http://www. intelligentbio.com), a division of Intelligent Automation Systems, Inc. (Cambridge, MA), has a highthroughput microarraying system that can dispense from 12 to 64 spots. Multiple reagent samples can be transferred from 108 source 96- or 384-well microplates onto a high-density array of spots on the surface of 100 microscope glass slides. The system is automated and able to run unattended for $24 \mathrm{hr}$.

TeleChem International, Inc. (Sunnyvale, CA) (http://arrayit.com) developed the ChipMaker 2 and ChipMaker 3 microspotting devices. These devices can be customized to attach to many high-end motion control systems such as the Cartesian Technologies PixSys PA Series, and detection can be achieved using commercially available biochip instrumentation by General Scanning, Genetic Micro Systems, Axon, Molecular Dynamics, and others. The ChipMaker 2 has a 32-pin print head, 100-150- $\mu \mathrm{m}$ feature size, uptake volume of $0.20 \mu \mathrm{l}$, and delivery volume of $1 \mathrm{~nL}$ and can produce 50 biochips of 25,000 feature in under $12 \mathrm{hr}$ with 25,000 features in a $1.8 \times 3.6-\mathrm{cm}$ area. The ChipMaker 3 has a 48-pin print head, 75-100- $\mu \mathrm{m}$ feature size, uptake volume of $0.20 \mu \mathrm{L}$, and delivery volume of $0.5 \mathrm{~nL}$ and can produce 50 biochips of 62,208 features in under $24 \mathrm{hr}$ with 62,208 features in a $1.8 \times 5.4-\mathrm{cm}$ area. The PixSys microarray may be configured with an additional dispensing mode using nQUAD dispenser heads with noncontact, ink jet-type dispensers with microsolenoid valves and syringe pumps.

The Packard Instrument Company (Meriden, CT) (http://www.packardinst.com) BioChip Arrayer uses four PiezoTip piezoelectric drop-on-demand tips on an $\mathrm{X}-\mathrm{Y}-\mathrm{Z}$ stage to provide noncontact dispensing for arraying onto glass, filters, and HydroGel 3D hydrophilic polymer matrix substrates. The PiezoTip can deliver $180-\mu \mathrm{m}$ spots at $250-\mu \mathrm{m}$ spacing. With a pitch of 200 $\mu \mathrm{m}$, a spot density of 1600 per $\mathrm{cm}^{2}$ is achieved.

A new approach for microarray analysis is being developed through a collaboration between Packard Instrument Company, Motorola, Inc., and a research team at Argonne National Laboratory under the director of Dr. Andrei Mirzabekov. The technology uses a MicroGel array, invented by Dr. Mirzabekov (Yershov et al. 1996), where each MicroGel is a three-dimen- 
sional polyacrylamide structure with picoliter-scale reaction chambers. The MicroGel arrays are being developed for a variety of microarraying applications. Packard Instrument Company has been developing the HydroGel chips based on MicroGel array technology and dispenses probe solutions onto the matrix with PiezoTip piezoelectric noncontact dispensers.

Rosetta Inpharmatics, Inc. (Kirkland, WA) (http:// www.rosettaimpharmatics.com) has developed FlexJet ink jet-based microarrays available only through scientific collaborations. FlexJet arrays are fabricated using an ink-jet oligonucleotide synthesizer, a modified version of a standard ink-jet printer, for the full genome of two organisms. The arrays are in situ-synthesized oligonucleotide arrays that employ a glass support on which oligonucleotides are formed using standard phosphoramidite chemistry. Microarrays with oligonucleotides from $>50,000$ human genes have been made on a nine-inch square glass surface (Blanchard and Friend 1999; Linsley et al. 1999).

Many more arraying technologies exist such as the Engineering Arts (Mercer Island, WA) (http://www. engineering-arts.com) Piezo electric-based automated pipetting instrument, GlaxoWellcome, Discovery Genetics (UK) Differential Gene Expression (DGE) highdensity cDNA arrays on nylon filters (T.C. Roberts, P.S. Robinson, T.Tait, R.W. Tothill, and D.M. Wallace, pers. comm.), the Hewlett Packard Company (Palo Alto, CA) thermal jet cDNA microarrays (Wiest et al. 1999), and the Incyte Microarray Systems (Fremont, CA) Gene Expression Microarrays (GEM) (Evertsz et al. 1999).

\section{Future Technologies}

A tremendous effort is being made in universities and in industry to develop revolutionary technology for genome analysis (Dahl and Strausberg 1996). The next few decades will see a dramatic change in the way biochemistry is performed in a typical laboratory. A few of the new technologies, spanning mass spectrometry and biochips to single molecule analysis, are described below.

\section{Mass Spectrometry}

Matrix-Assisted Laser Desorption-Ionization (MALDI), Time-of-Flight (TOF), and Electrospray Ionization (ESI) mass spectrometers hold promise as a technology that may one day permit rapid analysis for the sizeseparation step in DNA sequence analysis. Mass spectrometry would significantly increase the speed of the separation, detection, and data-acquisition processes for sequence analysis over conventional gel electrophoresis methods (Fitzgerald and Smith 1995). With MALDI-TOF mass spectrometry, the molecular weights of different molecules are measured directly, combining separation, detection, and characterization into a single step. In March 1998, SEQUENOM (San Diego, CA) (http://www.sequenom.com) sequenced 670 bases of the p53 gene using MALDI-TOF (Fu et al. 1998). For review articles on mass spectrometry, see Clark et al. (1999), Griffin et al. (1999), Aebersold et al. (2000), Deforce and Van den Eeckhout (2000), Fei and Smith (2000), Gatlin et al. (2000), Gevaert and Vandekerckhove (2000), Griffin and Smith (2000), Griffiths (2000), Guilhaus et al. (2000), Jackson et al. (2000), Johnston (2000), Li et al. (2000), Roepstorff (2000), and Yates (2000). A new mass spectrometric technique, charge reduction electrospray mass spectrometry (CREMS), is described in Scalf et al. (2000).

Mass spectrometry may also be used to compare thousands of individuals against a wide range of phenotypes and genetic markers to take advantage of the vast amounts of data available with sequencing of the human genome and other genomes. SEQUENOM developed the MassARRAY technology based on MALDI-TOF mass spectrometry for this purpose. MassARRAY combines SpectroCHIP miniaturized chip technology with high-fidelity enzymatic procedures, SpectroJET nanoliter dispensing, and SpectroREADER array-scanning mass spectrometry to process, analyze, and validate single nucleotide polymorphisms (SNPs) at high-throughput levels (Tang et al. 1999).

GeneTrace Systems Inc. (Alameda, CA) (http://www. genetrace.com) has developed high- throughput, automated mass spectrometry systems with liquid-phase expression technology and analytical methods for gene discovery, gene expression analysis, genotyping, and mutation scanning. Up to 20,000 SNPs can be analyzed per day. They are currently developing technology to simultaneously monitor the expression levels and functional state of hundreds of proteins within an experiment (Shaler et al. 1995; Monforte and Becker 1997; Butler et al. 1999a,b; Li et al. 1999; Lin et al. 1999).

To not lose the advantage afforded by the fast processing and analysis of samples using mass spectrometry, efficient sample preparation is necessary. Chan et al. (1999) describe a microfabricated polymer device for automated sample delivery of peptides for analysis by electrospray ionization tandem mass spectrometry. Other sample preparation methods are described in Gevaert et al. (2000) and Appella et al. (2000).

At MPIMG (Berlin, Germany) in the Lehrach Laboratory is a highly accurate and reliable positioning (HARP) system for microscale loading of MALDI-MS targets. The flight path of droplets dispensed from 16 piezo-jet dispensers (built in-house) is electroacoustically located and the droplets precisely positioned to obtain a positioning accuracy of $20 \mu \mathrm{m}$. A method has also recently been developed to implement solid-phase purification and concentration of peptide samples inside the tip of piezoelectric microdispensers for microscaled MALDI-MS analysis (M. Kalkum, pers. comm.; http://www.mpimg-berlin-dahlem.mpg.de/ kalkum).

A variety of companies manufacture mass spec- 
trometry systems. Amersham Pharmacia Biotech has a new Ettan MALDI-TOF mass spectrometry system for protein identification. The Biflex III from Bruker Daltonics, Inc. is a MALDI-TOF mass spectrometer with software for SNP detection and processing of acquired data into the correct genotypes.

\section{Biochips}

Biochip technology is increasing at an ever-faster rate that will soon yield exciting, revolutionary new methods for genome analysis and chemical analysis in general. Dr. D. Jed Harrison, Chair of the Micro-Total Analysis Systems ( $\mu$-TAS) '98 Conference, provides an excellent discussion of this field in the preface of Harrison and van den Berg (1998). He notes that emerging systems yield a high degree of parallelism for high sample throughput. The two main schemes used in miniaturized fluidic systems are "array based systems where sample or reagent is immobilized in large arrays on a plate or chip and fluids are flushed over the surface" or "microfluidic channels that form complex manifolds for fluid manipulation and controlled delivery of samples and reagents," often referred to as microfluidic systems.

As noted in the recent Micro Total Analysis Systems 2000 ( $\mu$ TAS 2000) conference (van den Berg et al. 2000), array-based systems are now commercially available and the research emphasis is on genome analysis, cell analysis, and "lab-on-a-chip" systems. Extensive developments include plastic microfabrication, centrifugal fluidic systems using plastic CD devices (see, e.g., Ekstrand et al. 2000; Kellogg et al. 2000), and electrokinetically pumped systems for fluid movement. Progress has been made in obtaining solutions to the difficult problems of detecting small amounts of sample and interfacing fluidic chips to the external environment. A variety of $\mu$-TAS examples are included in Harrison and van den Berg (1998) and van den Berg et al. (2000). For a review of microchip-based devices, see Cheng et al. (1996a,b), Colyer et al. (1997), Marshall and Hodgson (1997), Mastrangelo et al. (1998), Figeys and Pinto (2000), and McDonald et al. (2000).

A Digital Optical Chemistry (DOC) instrument has been developed by Dr. Harold (Skip) Garner (http:// pompous.swmed.edu) in collaboration with Texas Instruments (TI) and Affymetrix to enable a researcher to construct high- density, custom chips with oligonucleotide probes attached and then measure, archive, and analyze the expression level. DOC is based upon the Digital Micromirror Device (DMD) and the Digital Light Processor (DLP) developed by TI for micromachining and semiconductor electronics. TI uses this technology for very bright and color-true projection that replaces the Liquid Crystal Display (LCD). The DMD is a single chip with up to a couple million mechanically actuated micromirrors. The DMD and DLP technology are developed into a DOC instrument that produces very large, software reconfigurable, photolithographically produced oligonucleotide arrays. Chips are now being produced with over 192,000 features (oligonucleotides) per chip. The DOC is a unique UV light projector that can be used to manufacture biological/ chemical arrays using UV photochemistry or semiconductors using standard photoresist chemistry. It is basically an integration of the TI DLP technology with the Affymetrix optical deprotection photochemistry. This is exciting technology that provides a faster, cheaper method for producing biochips with similar capabilities as the original Affymetrix chips. Dr. Garner is using DOC chips to identify SNPs associated with cancer and cardiac disease (H. Garner, pers. comm.).

Other upcoming technologies for producing arrays for the analysis of genetic variation and function as well as other applications include the BeadArray technology by Illumina, Inc. (San Diego, CA) (http://www. illumina.com) and Laboratory-On-A-Bead (Qbeads) technology by Quantum Dot Corporation (Palo Alto, CA) (http://www.qdots.com). In the BeadArray technology, fiber optic self-assembled addressable arrays are filled with optically encoded libraries of 3-5 $\mu \mathrm{m}$ diameter beads or cells to simultaneously process up to three million assays. A multicolor labeling scheme is used to decode the beads (M. Chee, pers. comm.). This technology is based on research by David Watt of Tufts University (Ferguson et al. 1996; Lee and Watt 2000; Watt 2000).

Quantum dots (Qdots) are molecular-sized semiconductor nanocrystals that light up like LEDs and enable the detection and spectral encoding of biological materials from DNA to proteins (Alivisatos 1996). Only simple excitation with a blue or UV light, not a laser, is required for Qdots to emit any color of choice. Qdots are water soluble, photostable, multiplex, and provide high sensitivity. Quantum Dot Corporation is currently developing a wide variety of applications for Qdots including fluorescence microscopy and flow cytometry. The Qbeads technology is based on the use of Qdot particles to create spectral barcodes that enable high levels of multiplexing for genetic analysis. As few as 10 assays per well or potentially as many as millions of assays per well may be encoded (A. Watson, pers. comm.).

A number of chips for performing PCR have been designed that significantly decrease the cycling time and the sample volume required for analysis (see, e.g. Wilding et al. 1994; Burns et al. 1996; Cheng et al. 1996a,b; Northrup et al. 1995, 1998; Christel et al. 1998; Kopp et al. 1998). These designs include continuous-flow PCR or batch processes with total reaction times as short as $90 \mathrm{sec}$. The Cepheid (Sunnyvale, CA) SmartCycler is a multichannel thermal cycler with silicon-based reaction chambers and integral optical de- 
tection for real-time quantitation (Christel et al. 1998; Northrup et al. 1998).

Chip-based sequencers are being developed by researchers such as Manz et al. (1992), Harrison et al. (1992, 1993), Jacobson et al. (1994), Woolley and Mathies (1994), Morishima et al. (1997), Schmalzing et al. (1997, 1998, 1999), Suljak et al. (1998), Woolley et al. (1998), Liu et al. (1999), Scherer et al. (1999), Shi et al. (1999), Soper et al. (1999), and Liu et al. (2000). Dr. Richard Mathies (University of California, Berkeley) and his group have designed, built, and tested microfabricated capillary array electrophoresis systems to analyze 12, 48, and 96 DNA samples simultaneously (Harrison and van den Berg 1998). A unique rotary design runs 96 samples on 96 individual channels in a radial configuration and a rotary confocal scanning system (Simpson et al. 1998a,b). In a more recent design, >1000 capillaries are arranged around the surface of a cylinder and a rotating objective in the middle of the cylinder excites and collects fluorescence from labeled DNA fragments as they pass the capillary detection window (Scherer et al. 1999). A 1024-capillary array electrophoresis sequencer called the Monster CAE is being developed at Stanford in collaboration with UC Berkeley based on the rotary scanner system. It is run with dual 384-well plates and injects samples from submicroliter sample volumes (M. Jain, M. Au, R. Mathies, M. O'Keefe, M. Proctor, L. Roberts, J. Scherer, T. Willis, and R.W. Davis, pers. comm.). PCR reactors have also been successfully integrated with some of the microfabricated capillary electrophoresis systems (Woolley et al. 1996).

Dr. Andrew Ewing and his group at Pennsylvania State University have designed a system for parallel separations in microfabricated channels with capillary electrophoretic sample introduction. A stepper motor is used to translate the capillary outlet along the channel entrances to provide continuous sample introduction. Application of a constant potential across the capillary leads to a continuous migration of samples into the channel as the capillary is moved across the channel width. A separate potential is applied across the channel, resulting in electrophoretic separation of the analytes as they traverse the channel length. Detection is accomplished with an array of 100 individually addressed platinum electrodes spaced across the channel exit. This electrochemical array detection method (Wallingford and Ewing 1987) provides onchip detection, high sensitivity, and the spatial resolution needed to extract dynamic information from the sample being introduced across the channel width (Gavin and Ewing 1997; Suljak et al. 1998).

Many researchers are developing completely integrated systems or lab-on-a-chip devices for biochemical analysis that accept a sample, perform a multistep process, and analyze the result (Service 1998a,c; Kricka
1998; Hofmann et al. 1999). These steps may include extraction, purification, fluid movement, fluid mixing, reactions, and analysis. Just a sampling of some of the technologies is provided below. See Sedlak (1997) and van den Berg et al. (2000) for a more extensive list of companies and others involved in biochip research.

ACLARA BioSciences Inc. (Mountain View, CA) (http://www.aclara.com) uses electric fields to move fluids through capillaries on the surface of chips (LabCard devices) for the miniaturization, integration, and automation of complex, multistep biochemistry processes. They have demonstrated rapid, high-resolution electrophoretic separations in plastic chips (McCormick et al. 1997). Detection is with a confocal laserinduced fluorescence scanner. Producing chips in polymers such as acrylics as opposed to silicon enables the mass production of low-cost, ready-to-use, disposable chips (Effenhauser et al. 1997a,b; Sassi et al. 2000; T.D. Boone, H.H. Hooper, and D.S. Soane, 1998). Recent results (Boone et al. 2000) include a zero dead-volume 96-pin dispenser head to deliver 50-100 nL of different reagents simultaneously to 96 locations for screening assays. Evaporation control enables incubations up to $1 \mathrm{hr}$ for 200-nL volume assays. ACLARA has collaborations that use their disposable plastic LabCards, for example, with Applied Biosystems for a nanovolume Microfluidic Assay and Screening System (uMAS), Cellomics (Pittsburgh, PA) for a CellChip System, and Cepheid for a microfluidic system to perform automated measurements to simultaneously detect biological agents or genetically engineered variants.

Caliper Technologies Corporation (Mountain View, CA) (http://www.calipertech.com) is developing LabChip microfluidic devices with active fluid control, customized networks, sealed environments, assembly line processing, and parallel processing for a variety of genome analysis procedures including molecular purification and high-speed DNA separations. LabChip fluid channels are created photolithographically in either glass or plastic substrates. Electrokinetic fluid actuation and/or pressure are used to move fluids through microfluidic components and mixing occurs by diffusion (Jacobson et al. 1994). Integrated temperature control provides rapid heating and cooling at rates of $100 \mathrm{msec}$ for a $36^{\circ} \mathrm{C}$ temperature change. Samples are imported to the chip through a capillary that comes out of the chip (Sipper chips) and PCRs integrated with electrophoretic separation have been demonstrated for 10-nL samples (M. Knapp, pers. comm.).

The first commercially available LabChip technology-based system, the Agilent 2100 Bioanalyzer, was launched in September 1999 by Caliper and Agilent Technologies, Inc. (Palo Alto, CA) (http://www. agilent.com), formerly a subsidiary of Hewlett-Packard. This system can be used for nucleic acid analyses such as separation, sizing, quantifying, and identifying DNA

\section{Genome Research}


or RNA samples extracted from cells. Tens of thousands of experiments can be performed per day on a single, disposable chip. Caliper is currently developing LabChip systems for high-throughput screening, SNP genotyping, and other high-throughput applications. They developed a LibraryCard reagent array, a plastic card $10 \mathrm{~cm} \times 10 \mathrm{~cm}$, to dry and store nanograms of individual reagents. The reagents can be accessed and used on LabChip systems with Sipper chips.

Nanogen, Inc. (San Diego, CA) (http://www. nanogen.com) has developed an active programmable electronic matrix chip that has electronically addressable locations that can be independently controlled. Each location has a unique DNA oligonucleotide attached to the silicon surface. By applying a positive potential to each location, negatively charged target DNA is attracted and hybridization occurs within minutes (Jandreski 1995). Electronic multiplexing, concentration, hybridization, and stringency control is also possible right on the chip. In June 2000, Nanogen started selling its first commercial product, the Nanochip Molecular Biology Workstation with a fluorescent array scanner, fluidics station, and computer hardware and software, which allows users to array and analyze DNA on NanoChip cartridges in user-selected formats. The system uses electronically accelerated hybridization under very low salt conditions and no enzymes to avoid DNA conformation and secondary structure problems. Initial applications are for SNP scoring or genotyping. Chips are being developed with 25, 100, 400 , and 10,000 test sites for various applications such as infectious disease diagnostics, genomic research, genetic disease and cancer diagnostics, drug discovery, and gene expression (Heller et al. 1998; Edman et al. 2000; Radtkey et al. 2000; Westin et al. 2000).

Orchid BioSciences, Inc. (Princeton, NJ) (http:// www.orchidbio.com) is developing microfluidic glass chips to enable high-throughput chemical synthesis, genomics, DNA analysis, screening, and diagnostics. The thin, three-dimensional chips have multilayered wafers where each wafer contains a large array of reactors with a reaction well, electrohydrodynamic pumping, and channels for vertical and horizontal fluid flow. There are no moving parts, making large-scale integration feasible and reliable. The goal is to perform 10,000 reactions on a single chip with volumes of 100 $\mathrm{nL}$ to $2 \mu \mathrm{L}$ per reaction. Current Chemtel chips contain 96,384 , or 1536 wells. Precision fluid delivery is with a capillary break mechanism. The chips use solidsupport chemistry and provide temperature control of the reactor wells thus enabling solid phase chemistry, solution phase chemisty, temperature control, and purification by resin capture. Chips systems include Chemtel chips and the MassStream processor for analytical chemistry, ChemStream processor for combinatorial chemistry, and SNPstream processor for genom- ics. Orchid has an analytical collaboration with Advanced Bioanalytical Sytems (Ithaca, NY) for microchip-based electrospray mass spectrometry nozzles (R. Swenson 1999).

Recently Orchid Biosciences has been focusing on high-throughput SNP scoring with their SNP-IT single base primer extension technology (Picoult-Newbert et al. 1999). Combining SNP-IT with their microfluidics technology in their high-throughput MegaSNPatron facility may yield fast, cost-effective, high-throughput SNP analysis. In June 2000, Amersham Pharmacia Biotech gained access, through a nonexclusive license, to develop and market Orchid's SNP-IT technology for applications on capillary and slab gel DNA sequencers.

Researchers at the University of Michigan are developing an integrated DNA analysis system that includes a fluid injection system with hydrophobic patterning, an air-driven fluid pump, a temperaturecontrolled reaction chamber, and an electrophoresis and fluorescence detection system. The device typically uses 100-nL drops with temperature control within $\pm 0.1^{\circ} \mathrm{C}$. All of the components are microfabricated on the same wafer and require no external lenses, heaters, or mechanical pumps. Constant temperature amplification using Strand Displacement Amplification (SDA) and gel electrophoresis have been successfully demonstrated on these devices (Burns et al. 1998). Microfabricated plastic electrophoresis chips have also been constructed on polycarbonate substrates and have successfully separated double-stranded DNA. This technology has the potential for low-cost fabrication of disposable, single-use, electrophoresis devices (Webster et al. 1998).

Gamera Bioscience Corporation (Medford, MA) (http://www.gamerabioscience.com) has recently developed the "lab-on-a-disc" or LabCD System. This microfluidic platform uses a modified CD player and disposable compact disc with an electrical circuit layer for valving, heating, and thermal cycling to accommodate a variety of microscale analytical processes. Fluid is moved along microscale fluid paths by capillary action and centrifugal forces generated by disc rotation. One of Gamera's goals is to be the first automated, nonrobotic device to integrate sample preparation with DNA amplification in one step on a single instrument.

It remains to be seen whether these biochip devices will be useful for large-scale de novo sequencing. If so, they will revolutionize the operations in a largescale sequencing facility. Regardless, they will most definitely make a huge impact and enable the use of genome analysis for applications such as resequencing, SNP analysis, gene expression profiling, drug screening, medical diagnostics, and point-of-use agricultural testing. 


\section{Single Molecule Analysis}

A variety of novel approaches based on single molecule analysis are being investigated to provide revolutionary approaches for DNA sequencing and analysis (Davis et al. 1991; Chen and Dovichi 1996; Fernandes 1998; Haab and Mathies 1998; Nie and Zare 1998; Rich 1998; Akeson et al. 1999; Herrick and Bensimon 1999; Ishikawa 1999; Moore et al. 1999; Yeung 1999; Bustamante et al. 2000; Deamer and Akeson 2000; Jett et al. 2000; Krylov and Dovichi 2000; Van Craenenbroeck and Engelborghs 2000). One example is the research by Dr. Deamer at the University of California, Santa Cruz and Dr. Branton at Harvard University to develop single molecule electrophoresis (Akeson et al. 1999; Akeson and Deamer 1999; Deamer and Akeson 2000; Service 2000). Experiments have been performed to determine whether a nanoscale hydrated pore embedded in a nonconducting support could transport nucleic acid anions single file between two aqueous compartments under an applied voltage. Using an $\alpha$-hemolysin pore, the researchers demonstrated that adding singlestranded DNA to the solution immersing the pore results in transient blockades of the monovalent ion current within the pore. The blockades are due to nucleic acid transport through the pore and that transport correlates with nucleic acid length and concentration (Kasianowicz et al. 1996; Alper 1999). If successful for single-base pair resolution, this approach has the potential to provide an extremely rapid, low-cost method for sequencing and would eliminate the need for cloning. Simultaneously, Dr. George Church of the Harvard Medical School (Church et al. 1998; http:// arep.med.harvard.edu/gmc_pub.html) conceived of a similar approach in which double-stranded DNA is passed through a phospholambdin channel.

In another approach, SEQ Ltd (Princeton, NJ), now Praelux, Inc. (Lawrenceville, NJ) is developing a singlemolecule DNA sequencer that involves isolation and exonucleolytic digestion of individual strands of DNA $(\sim 50 \mathrm{~kb})$. The cleaved nucleotides are immobilized on a surface, in order, and subsequently detected and identified (Macklin et al. 1996). Again, this approach may yield a very rapid, low cost sequencing method. See also Jett et al. (1989) and Davis et al. (1991).

A Harvard/MIT group recently reported on a novel atomic imaging microscope for SNP analysis (Service 2000; Wooley et al. 2000). The atomic force microscope (AFM), equipped with a single-walled carbon nanotube probe, can scan a DNA strand and identify uniquely shaped reporter molecules engineered to tag genetic variations. Instead of adding a fluorescent signal to a base as in sequencing, an oligo with a reporter compound is bound to a known SNP location to enable SNPs to be observed directly on a chromosome. Haplotypes in 10-kb-size DNA fragments have been directly determined with this new technique. It may be possible to analyze sequences of 100,000 bases or even parallelize the method by running arrays of hundreds of the modified AFM tips simultaneously.

\section{Conclusions}

New technology for genomics is an interdisciplinary effort, requiring contributions from a range of fields that previously have never been so closely interconnected, including input from molecular biologists, geneticists, chemists, physicists, mathematicians, computer scientists, and engineers (Meldrum 1995). Automation is essential to increase efficiency, quality, and reliability of DNA processing and analysis, and, importantly, to reduce overall cost. As technology develops for biochips and the like, dramatic changes will occur in biochemical processing. Miniaturization through microfabrication processing promises to revolutionize biochemistry just as the miniaturization of electronics transformed the computer industry. The information produced as a result of applying this new technology to genome analysis will lead to a new, exciting age in genetic-medicine (Figeys and Pinto 2000).

\section{ACKNOWLEDGMENTS}

Deirdre Meldrum thanks the many people whose generous personal communications made this article possible.

\section{REFERENCES}

Aebersold, R., Hood, L.E., and Watts, J.D. 2000. Equipping scientists for the new biology. Nat. Biotechnol. 18: 359.

Ahmadian, A., Gharizadeh, B., Gustafsson, A.C., Sterky, F., Nyren, P., Uhlen, M., and Lundeberg, J. 2000. Single-nucleotide polymorphism analysis by pyrosequencing. Anal. Biochem. 280: $103-110$.

Akeson, M., Branton, D., Kasianowicz, J.J., Brandin, E., and Deamer, D.W. 1999. Microsecond time-scale discrimination among polycytidylic acid, polyadenylic acid, and polyuridylic acid as homopolymers or as segments within single RNA molecules. Biophys. J. 77: 3227-3233.

Alexjander, S., and Deamer, D. 1999. The infrared frequencies of DNA bases: Science and art. IEEE Eng. Med. Biol. Mag. 18: 74-79.

Alivisatos, A.P. 1996. Semiconductor clusters, nanocrystals, and quantum dots. Science 271: 933.

Alper, J. 1999. From the bioweapons trenches, new tools for battling microbes. Science 284: 1754-1755.

Anderson, R.C., Bogdan, G.J., Puski, A., and Su, X. 1998. Advances in integrated genetic analysis. In Micro Total Analysis Systems '98 (eds. D.J. Harrison and A. van den Berg), pp. 11-16. Kluwer Academic Publishers, Boston.

Andersson, H., Ahmadian, A., van der Wijngaart, W., Nilsson, P., Enoksson, P., Uhlen, M., and Stemme, G. 2000. Micromachined flow-through filter-chamber for solid phase DNA analysis. In Micro total analysis systems 2000 (ed. A.van den Berg, W. Olthuis, and P. Bergveld), pp. 473-476. Kluwer Academic Publishers, Boston, MA.

Ansorge, W. 1997. Development of microanalytical techniques. In EMBL 1997 research reports, pp. 9-19. EMBL, Heidelberg, Germany.

Ansorge, W., Sproat, B., Stegemann, J., and Schwager, C. 1986. A non-radioactive automated method for DNA sequence determination. J. Biochem. Biophys. Methods 13: 315-323.

Ansorge, W., Sproat, B., Stegemann, J., Schwager, C., and Zenke, M. 1987. Automated DNA sequencing: Ultrasensitive detection of fluorescent bands during electrophoresis. Nucleic Acids Res. 15: $4594-4602$. 
Ansorge, W., Sproat, B., Stegemann, J., Schwager, C., and Zenke, M. 1987. Automated DNA sequencing: Ultrasensitive detection of fluorescent bands during electrophoresis. Nucleic Acids. Res. 15: $4594-4602$.

Apella, E., Arnott, D., Sakaguchi, K., and Wirth, P.J. 2000. Proteome mapping by two-dimensional polyacrylamide gel electrophoresis in combination with mass spectrometric protein sequence analysis. EXS 88: 1-27.

Bashkin, J., Marsh, M., Barker, D., and Johnston, R. 1996a. DNA sequencing by capillary electrophoresis with a hydroxyethylcellulose sieving buffer. Appl. Theor. Electrophor. 6: 23-28.

Bashkin, J., Bartosiewicz, M., Roach, D., Leong, J., Barker, D., and Johnston, R. 1996b. Implementation of a capillary array electrophonesis instrument. J. Capill. Electrophor. 3: 61-68.

Behr, S., Matzig, M., Levin, A., Eickhoff, H., and Heller, C. 1999. A fully automated multicapillary electrophoresis device for DNA analysis. Electrophoresis 20: 1492-1507.

Blanchard, A.P. and Friend, S.H. 1999. Cheap DNA arrays-it's not all smoke and mirrors. Nat. Biotechnol. 17: 953.

Boone, T.D., Ricco, A.J., Gooding, P., Bjornson, T.O., Singh, S., Xiao, V., Gibbons, I., Williams, S.J., and Tan, H. 2000. Sub-microliter assays and DNA analysis on plastic microfluidics. In Micro total analysis systems 2000 (ed. A. van den Berg, W. Olthuis, and P. Bergveld), pp. 541-544. Kluwer Academic Publishers, Boston, MA.

Boone, T.D., Hooper, H.H., and Soane, D.S. 1998. Integrated chemical analysis on plastic microfluidic devices. Solid State Sensor and Actuator Workshop Proceedings, Hilton Head, South Carolina 87-92.

Brown, M.P.S., Grundy, W.N., Lin, D., Cristianini, N., Sugnet, C.W., Furey, T.S., Ares, M., and Haussler, D. 2000. Knowledge-based analysis of microarray gene expression data by using support vector machines. Proc. Natl. Acad. Sci. 97: 262-267.

Burns, M.A., Mastrangelo, C.H., Sammarco, T.S., Man, P.F., Webster, J.R., Johnson, B.N., Foerster, B., Jones, D.K., Fields, Y., Kaiser, A.R., et al. 1996. Microfabricated structures for integrated DNA analysis. Proc. Natl. Acad. Sci. 93: 5556-5561.

Burns, M.A., Johnson, B.N., Brahmasandra, S.N., Handique, K., Webster, J.R., Krishnan, M., Sammarco, T.S., Man, P.M., Jones, D., Heldsinger, D., et al. 1998. An integrated nanoliter DNA analysis device. Science 282: 484-487.

Bustamante, C., Smith, S.B., Liphardt, J., and Smith, D. 2000. Single-molecule studies of DNA mechanics. Curr. Opin. Struct. Biol. 10: 279-285

Butler, J.M., Li, J., Shaler, T.A., Monforte, J.A., and Becker, C.H 1999a. Reliable genotyping of short tandem repeat loci without an allelic ladder using time-of-flight mass spectrometry. Int. J. Legal Med. 112: 45-49.

Butler, J., Shaler, T., Royer, S., andMonforte, J. 1999b. High-throughput multiplexed SNP genotyping by mass spectrometry. Microb. Comparat. Genomics 4: 111.

Carrilho, E., Ruiz-Martinez, M.C., Berka, J., Smirnov, I., Goetzinger, W., Miller, A.W., Brady, D., and Karger, B.L. 1996. Rapid DNA sequencing of more than 1000 bases per run by capillary electrophoresis using replaceable linear polyacrylamide solutions. Anal. Chem. 68: 3305-3313.

Castellino, A.M. 1997. When the chips are down. Genome Res. 7: 943-946.

Chan, J.H., Timperman, A.T., Qin, D., and Aebersold, R. 1999. Microfabricated polymer devices for automated sample delivery of peptides for analysis by electrospray ionization tandem mass spectrometry. Anal. Chem. 71: 4437-4444.

Chen, D.Y. and Dovichi, N.J. 1996. Single molecule detection in capillary electrophoresis: Molecular ShotNoise as a fundamental limit to chemical analysis. Anal. Chem. 68: 690-696.

Cheng, J., Fortina, P., Surrey, S., Kricka, L.J., and Wilding, P. 1996a. Microchip-based devices for molecular diagnosis of genetic diseases. Mol. Diag. 1: 183-199.

Cheng, J., Shoffner, M.A., Hvichia, G.A., Kricka, L.J., and Wilding, P. 1996b. Chip PCR. II. Investigation of different PCR amplification systems in microfabricated silicon-glass chips. Nucleic Acids Res. 24: $380-385$

Christel, L.A., Petersen, K., McMillan, W., and Northrup, M.A. 1998 Nucleic acid concentration and PCR for diagnostic applications. In Micro total analysis systems '98 (ed. D.J. Harrison and A. van den Berg), pp. 277-280. Kluwer Academic Publishers, Boston, Massachusetts.

Church, G.M., Deamer, D.W., Branton, D., Baldarelli, R., and Kasianowicz, J. 1998. Characterization of individual polymer molecules based on monomer-interface interactions. U.S. Patent No. 5795782

Clark, M.D., Panopoulou, G.D., Cahill, D.J., Bussow, K., and Lehrach, H. 1999. Construction and analysis of arrayed cDNA libraries. Methods Enzymol. 303: 205-233.

Cohen, A.S. and Karger, B.L. 1987. High-performance sodium dodecyl sulfate polyacrylamide gel capillary electrophoresis of peptides and proteins. Chromatography 397: 409-417.

Cohen, A.S., Paulus, A., and Karger, B.L. 1987. High-performance capillary electrophoresis using open tubes and gels. Chromatographia 24: 15-24.

Collins, F.S., Patrinos, A., Jordan, E., Chakravarti, A., Gesteland, R., and Walters, L. 1998. New goals for the U.S. Human Genome Project. Science 282: 682-689.

Colyer, C.L., Tang, T., Chiem, N., andHarrison, D.J. 1997. Clinical potential of microchip capillary electrophoresis systems. Electrophoresis 18: 1733-1744.

Crabtree, H.J., Bay, S.J., Lewis, D.F., Zhang, J., Coulson, L.D., Fitzpatrick, G.A., Delinger, S.L., Harrison, D.J., and Dovichi, N.J. 2000. Construction and evaluation of a capillary array DNA sequencer based on a micromachined sheath-flow cuvette. Electrophoresis 21: 1329-1335.

Dahl, C.A. and Strausberg, R.L. 1996. Revolutionizing biology through leveraging technology. IEEE EMB 15: 106-110.

Davis, L.M., Fairfield, F.R., Harger, C.A., Jett, J.H., Keller, R.A., Hahn, J.H., Krakowski, L.A., Marrone, B.L., Martin, J.C., and Nutter, H.L. 1991. Rapid DNA sequencing based upon single molecule detection. Genet. Anal. Tech. Appl. 8: 1-7.

Deamer, D.W. and Akeson, M. 2000. Nanopores and nucleic acids: Prospects for ultrarapid sequencing. Trends Biotechnol. 18: $147-151$.

Deforce, D.L. and Van den Eeckhout, E.G. 2000. Analysis of oligonucleotides by ESI-MS. Adv. Chromatogr. 40: 539-566.

DeRisi, J.L., Iyer, V.R., and Brown, P.O. 1997. Exploring the metabolic and genetic control of gene expression on a genomic scale. Science 278: 680-686.

Dovichi, N.J. 1997. DNA sequencing by capillary electrophoresis. Electrophoresis 18: 2393-2399.

- 1999. Development of DNA sequencer. Science 285: 1016.

Durick, K., Mendlein, J., and Xanthopoulos, K. 1999. Hunting with traps: Genome-wide strategies for gene discovery and functional analysis. Genome Res. 9: 1019-1025.

Edman, C.F., Mehta, P., Press, R., Spargo, C.A., Walker, G.T., and Nerenberg, M. 2000. Pathogen analysis and genetic predisposition testing using microelectronic arrays and isothermal amplification. J. Investig. Med. 48: 93-101.

Effenhauser, C.S., Bruin, G.J.M., and Paulus, A. 1997a. Integrated chip-based capillary electrophoresis. Electrophoresis 18: 2203-2213.

Effenhauser, C.S., Bruin, G.J.M., Paulus, A., and Ehrat, M. 1997b. Integrated capillary electrophoresis on flexible silicon microdevices: Analysis of DNA restriction fragments and detection of single DNA molecules on microchips. Anal. Chem. 69: 3451-3457.

Ekstrand, G., Holmquist, C., Orlefors, A.E., Hellman, B., Larsson, A., and Andersson, P. 2000. Microfluidics in a rotating CD. In Micro total analysis systems 2000 (ed. A.van den Berg, W. Olthuis, and P. Bergveld), pp. 311-314. Kluwer Academic Publishers, Boston, MA.

Erfle, H., Ventzki, R., Voss, H., Rechmann, S., Benes, V., Stegemann, V., and Ansorge, W. 1997. Simultaneous loading of 200 sample lanes for DNA sequencing on vertical and horizontal, standard 
and ultrathin gels. Nucleic Acids Res. 25: 2229-2230.

Evans, T. 2000. Developing and commercializing a DNA sequencer. IEEE EMB 19: 117-120.

Evensen, H.T., Meldrum, D.R., Saenphimmachak, C., and Dixon, E.E. 1999. High-density small-volume gel loading directly from capillary tubes. BioTechniques 27: 974-978.

Evertsz, E., Au-Young, J., Ruvolo, M., Daniel, S., Lim, A.C., Theriault, T., and Reynolds, M. 1999. Detection of GEM cross-reactivity within gene families. Microb. Comparat. Genomics 4: 85.

Ewing, B. and Green, P. 1998. Base-calling of automated sequencer traces using phred. II. Error probabilities. Genome Res. 8: $186-194$

Ewing, B., Hillier, L., Wendl, M.C., and Green, P. 1998. Base-calling of automated sequencer traces using phred. I. Accuracy assessment. Genome Res. 8: 175-185.

Fei, Z. and Smith, L.M. 2000. Analysis of single nucleotide polymorphisms by primer extension and matrix-assisted laser desorption/ionization time-of-flight mass spectrometry. Rapid Commun. Mass Spectrom. 14: 950-959.

Ferguson, J.A., Boles, T.C., Adams, C.P., and Walt, D.R. 1996. A fiber-optic DNA biosensor microarray for the anlaysis of gene expression. Nat. Biotechnol. 14: 1681-1684.

Fernandes, P.B. 1998. Technological advances in high-throughput screening. Curr. Opin. Chem. Biol. 2: 597-603.

Figeys, D. and Pinto, D. 2000. Lab-on-a-chip: A revolution in biological and medical sciences. Anal. Chem. 72: 330A-335A.

Fitzgerald, M.C. and Smith, L.M. 1995. Mass spectrometry of nucleic acids: The promise of matrix-assisted laser desorption-ionization (MALDI) mass spectrometry. Annu. Rev. Biophys. Biomol. Struct. 24: $117-140$.

Fodor, S.P.A., Read, J.L., Pirrung, M.C., Stryer, L., Lu, A.T., and Solas, D. 1991. Light-directed, spatially addressable parallel chemical synthesis. Science 251: 767-773.

Fu, D.J., Tang, K., Braun, A., Reuter, D. Darnhofer-Demar, B., Little, D.P., O'Donnell, M.J., Cantor, C.R., and Koster, H. 1998. Sequencing exons 5 to 8 of the p53 gene by MALDI-TOF mass spectrometry. Nat. Biotechnol. 16: 381-384.

Gao, Q. and Yeung, E.S. 2000. High-throughput detection of unknown mutations by using multiplexed capillary electrophoresis with poly (vinylpyrrolidone) solution. Anal. Chem. 72: 2499-2506.

Gatlin, C.L., Eng, J.K., Cross, S.T., Detter, J.C., and Yates, J.R., 3rd. 2000. Automated identification of amino acid sequence variations in proteins by HPLC/microspray tandem mass spectrometry. Anal. Chem. 72: 757-763.

Gavin, P.F. and Ewing, A.G. 1997. Characterization of electrochemical array detection for continuous channel electrophoretic separations in micrometer and submicrometer channels. Anal. Chem. 69: 3838-3845.

Gevaert, K. and Vandekerckhove, J. 2000. Protein identification methods in proteomics. Electrophoresis 21: 1145-1154.

Gevaert, K., Houthaeve, T., and Vandekerckhove, J. 2000 Techniques for sample preparation including methods for concentrating peptide samples. EXS 88: 29-42.

Gordon, D., Abajian, C., and Green, P. 1998. Consed: A graphical tool for sequence finishing. Genome Res. 8: 195-202.

Griffin, T.J. and Smith, L.M. 2000. Single-nucleotide polymorphism analysis by MALDI-TOF mass spectrometry. Trends Biotechnol. 18: $77-84$.

Griffin, T.J., Hall, J.G., Prudent, J.R., and Smith, L.M. 1999. Direct genetic analysis by matrix-assisted laser desorption/ionization mass spectrometry. Proc. Natl. Acad. Sci. 96: 6301-6306.

Griffiths, W.J. 2000. Nanospray mass spectrometry in protein and peptide chemistry. EXS 88: 69-79.

Guilhaus, M., Selby, D., and Mlynski, V. 2000. Orthogonal acceleration time-of-flight mass spectrometry. Mass Spectrom. Rev. 19: $65-107$.

Gunderson, K.L., Huang, X.C., Morris, M.S., Lipshutz, R.J., Lockhart, D.J., and Chee, M.S. 1998. Mutation detection by ligation to complete n-mer DNA arrays. Genome Res. 8: 1142-1153.

Haab, B.B. and Mathies, R.A. 1998. Single molecule DNA detection in microfabricated capillary electrophoresis chips. Proc. of Int. Soc. Opt. Engin.-SPIE 3259: 104-111.

Harrington, C.A., Rosenow, C., and Retief, J. 2000. Monitoring gene expression using DNA microarrays. Curr. Opin. Microbiol. 3: $285-291$.

Harris, T.M., Massimi, A., and Childs, G. 2000. Injecting new ideas into microarray printing. Nat. Biotechnol. 18: 384-385.

Harrison, D.J. and van den Berg, A., eds. 1998. Micro total analysis systems '98. Proceedings of the $\mu$ TAS '98 Workshop, Banff, Canada, 13-16 October 1998. Kluwer Academic Publishers, Boston, Massachusetts.

Harrison, D.J., Fluri, K., Seiler, K., Fan, Z., Effenhauser, C.S., and Manz, A. 1993. Micromachining a miniaturized capillary electrophoresis-based chemical analysis system on a chip. Science 261: 895-897.

Harrison, D.J., Manz, A., Fan, Z., Ludi, H., and Widmer, H.M. 1992. Capillary electrophoresis and sample injection systems integrated on a planar glass chip. Anal. Chem. 64: 1926-1932.

Heller, M.J., Holmsen, A., Ackley, D., Tu, G., Sosnowski, R., Butler, B., Dillion, P., Nerenberg, M., Raymond, D., Sheldon, E., et al. 1998. An integ rated microelectronic hybridization system for genomic research and diagnostic applications. In Micro total analysis systems '98 (ed. D.J. Harrison and A. van den Berg), pp. 221-224. Kluwer Academic Publishers, Boston, Massachusetts.

Herrick, J. and Bensimon, A. 1999. Single molecule analysis of DNA replication. Biochimie 81: 859-871.

Hofmann, O., Che, D., Cruickshank, K.A., and Muller, U.R. 1999. Adaptation of capillary isoelectric focusing to microchannels on a glass chip. Anal. Chem. 71: 678-686.

Hood, L.E., Hunkapiller, M.W., and Smith, L.M. 1987. Automated DNA sequencing and analysis of the human genome. Genomics 1: 201-212.

Huang, G.M. 1999. High-throughput DNA sequencing: A genomic data manufacturing process. DNA Seq. 10: 149-153.

Hunkapiller, T., Kaiser, R.J., Koop, B.K., and Hood, L. 1991. Large-scale and automated DNA sequence determination. Science 254: $59-67$.

Hyman, E.D. 1988. A new method of sequencing DNA. Anal. Biochem. 174: 423-436.

Ishikawa, M. 1999. DNA sequencing based on single molecule detection. Tanpakushitsu Kakusan Koso 44: 2019-2023.

Jackson, P.E., Scholl, P.F., and Groopman, J.D. 2000. Mass spectrometry for genotyping: An emerging tool for molecular medicine. Mol. Med. Today 6: 271-276.

Jacobson, S.C., Koutny, L.B., Hergenroder, R., Moore, A.W., Jr., and Ramsey, J.M. 1994. Microchip capillary electrophoresis with an integrated postcolumn reactor. Anal. Chem. 66: 3472-3476.

Jandreski, M.A. 1995. Novel methods of DNA analysis. Clinics Lab. Med. 15: 817-837.

Jett, J.H., Keller, R.A., Martin, J.C., Marrone, B.L., Moyzis, R.K., Ratliff, R.L., Seitzinger, N.K., Shera, E.B., Stewart, C.C. 1989. High-speed DNA sequencing: An approach based upon fluorescence detection of single molecules. J. Biomol. Struct. Dynam. 7: 301-309.

Jett, S.D., Cherny, D.I., Subramaniam, V., and Jovin, T.M. 2000. Scanning force microscopy of the complexes of p53 core domain with supercoiled DNA. J. Mol. Biol. 299: 585-592.

Johnston, M.V. 2000. Sampling and analysis of individual particles by aerosol mass spectrometry. J. Mass Spectrom. 35: 585-595.

Kasianowicz, J., Brandin, E., Branton, D., and Deamer, D.W. 1996. Characterization of individual polynucleotide molecules using a membrane channel. Proc. Natl. Acad. Sci. 93: 13770-13773.

Kellogg, G.J., Arnold, T.E., Carvalho, B.L., Duffy, D.C., and Sheppard, N.F., Jr. 2000. Centrifugal microfluidics: Applications. In Micro total analysis systems 2000 (ed. A. van den Berg, W. Olthuis, and P. Bergveld), pp. 239-242. Kluwer Academic Publishers, Boston, MA.

Kheterpal, I. and Mathies, R.A. 1999. Capillary array electrophoresis DNA sequencing. Anal. Chem. 71: 31A-37A.

Kheterpal, I., Scherer, J.R., Clark, S.M., Radhakrishnan, A., Ju, J.Y., Ginther, C.L., Sensabaugh, G.F., and Mathies, R.A. 1996. DNA 
sequencing using a four-color confocal fluorescence capillary array scanner. Electrophoresis 17: 1852-1859.

Kopp, M.U., de Mello, A.J., and Manz, A. 1998. Chemical amplification: Continuous flow PCR on a chip. Science 280: $1046-1048$.

Kostichka, A.J., Marchbanks, M., Brumley, R.L., Drossman, H., and Smith, L.M. 1992. High speed automated DNA sequencing in ultrathing slab gels. Bio/Technology 10: 78-81.

Kricka, L.J. 1998. Revolution on a square centimeter. Nat. Biotechnol. 16: $513-514$.

Krylov, S.N. and Dovichi, N.J. 2000. Single-cell analysis using capillary electrophoresis: Influence of surface support properties on cell injection into the capillary. Electrophoresis 21: 767-773.

Lamture, J.B., Beattie, K.L., Burke, B.E., Eggers, M.D., Ehrlich, D.J., Fowler, R., Hollis, M.A., Kosicki, B.B., Reich, R.K., Smith, S.R., et al. 1994. Direct detection of nucleic acid hybridization on the surface of a charge coupled device. Nucleic Acids Res. 22: 2121-2125.

Lander, E.S. 1999. Array of hope. Nat. Genet. 21:(Suppl) 3-4.

Lee, M. and Walt, D.R. 2000. A fiber-optic microarray biosensor using aptamers as receptors. Anal. Biochem. 282: 142-146.

Lennon, G.G. 2000. High-throughput gene expression analysis for drug discovery. Drug Discov. Today 5: 59-66.

Li, J., Butler, J.M., Tan, Y., Lin, H., Royer, S., Ohler, L., Shaler, T.A., Hunter, J.M., Pollart, D.J., Monforte, J.A., et al. 1999. Single nucleotide polymorphism determination using primer extension and time-of-flight mass spectrometry. Electrophoresis 20: $1258-1265$.

Li, L., Garden, R.W., and Sweedler, J.V. 2000. Single-cell MALDI: A new tool for direct peptide profiling. Trends Biotechnol. 18: $151-160$.

Lin, H., Hunter, J.M., and Becker, C.H. 1999. Laser desorption of DNA oligomers larger than one kilobase from cooled 4-nitrophenol. Rapid Commun. Mass Spectrom. 13: 2335-2340.

Linsley, P., Blanchard, A., Burchard, J., Coffey, E., Dai, H., He, Y., Hughes, T., Jones, A., Kobayshi, S., Lee, A., et al. 1999. Use of FlexJet inkjet-based technology to construct 50k human gene microarrays. Microb. Comparat. Genomics 4: 90.

Lipshutz, R.J., Fodor, S.P., Gingeras, T.R., and Lockhart, D.J. 1999. High density synthetic oligonucleotide arrays. Nat. Genet. 21:(Suppl) 20-24.

Liu, S., Ren, H., Gao, Q., Roach, D.J., Loder, R.T., Jr., Armstrong, R.M., Mao, Q., Blaga, I., Barker, D.L., et al. 2000. Parallel DNA sequencing on microfabricated electrophoresis chips. In Micro total analysis systems 2000 (ed. A. van den Berg, W. Olthuis, and P. Bergveld), pp. 477-480. Kluwer Academic Publishers, Boston, MA.

Liu, S.R., Shi, Y.N., Ja, W.W., and Mathies, R.A. 1999. Optimization of high-speed DNA sequencing on microfabricated capillary electrophoresis channels. Anal. Chem. 71: 566-573.

Lockhart, D.J., Dong, H, Byrne, M.C., Follettie, M.T., Gallo, M.V., Chee, M.S., Mittman, M., Wang, C., Kobyashi, M., Horton, H., et al. 1996. Expression monitoring by hybridization to high-density oligonucleotide arrays. Nat. Biotechn. 14: 1675-1680.

Macklin, J., Trautman, J.K., Harris, T.D., and Brus, L.E. 1996. Imaging and time-resolved spectroscopy of single molecules at an interface. Science 272: 255-258.

Madabhushi, R.S., Vainer, M., Dolnik, V., Enad, S., Barker, D.L., Harris, D.W., and Mansfield, E.S. 1997. Versatile low-viscosity sieving matrices for nondenaturing DNA separations using capillary array electrophoresis. Electrophoresis 1: 104-111.

Madabhushi, R.S. 1998. Separation of 4-color DNA sequencing extension products in noncovalently coated capillaries using low viscosity polymer solutions. Electrophoresis 2: 224-230.

Manz, A., Harrison, D.J., Verpoorte, E.M.J., Fettinger, J.C., Paulus, A. Ludi, H., and Widmer, H.M. 1992. Planar chips technology for miniaturization and integration of separation techniques into monitoring systems: Capillary electrophoresis on a chip. J. Chromotography 593: 253-258.

Marshall, A. and Hodgson, J. 1998. DNA chips: An array of possibilities. Nat. Biotechnol. 16: 27-31.
Mastrangelo, C.H., Burns, M.A., and Burke, D.T. 1998. Microfabricated devices for genetic diagnostics. Proc. IEEE 86: $1769-1787$.

McCormick, R.M., Nelson, R.J., Alonso-Amigo, M.G., Benvegnu, D.J., and Hooper, H.H. 1997. Microchannel electrophoretic separations of DNA in injection-molded plastic substrates. Anal. Chem. 69: 2626-2630.

McDonald, J.C., Duffy, D.C., Anderson, J.R., Chiu, D.T., Wu, H., Schueller, O.J., and Whitesides, G.M. 2000. Fabrication of microfluidic systems in poly(dimethylsiloxane). Electrophoresis 21: $27-40$.

McWhorter, S. and Soper, S.A. 2000. Near-infrared laser-induced fluorescence detection in capillary electrophoresis. Electrophoresis 21: $1267-1280$.

Meldrum, D.R. 1995. The interdisciplinary nature of genomics. IEEE EMB 14: 443-448.

- 2000. Automation for genomics, Part One: Preparation for sequencing. Genome Res. 10: 1081-1092.

Monforte, J.A. and Becker, C.H.. 1997. High-throughput DNA analysis by time-of-flight mass spectrometry. Nat. Med. 3: 360-362.

Moore, K.J., Turconi, S., Ashman, S., Ruediger, M., Haupts, U., Emerick, V., and Pope, A.J. 1999. Single molecule detection technologies in miniaturized high throughput screening: Fluorescence correlation spectroscopy. J. Biomol. Screen. 4: 335-354.

Morishima, K., Fukuda, T., Arai, F., and Yoshikawa, K. 1997. Microflow system and transportation of DNA molecule by dielectrohoretic force utilizing the conformational transition in the higher order structure of DNA molecule. Proc. IEEE The Tenth Annual International Workshop on Micro Electro Mechanical Systems, Nagoya, Japan, 389-394.

Mullikin, J.C. and McMurragy, A.A. 1999. Techview: DNA sequencing. Sequencing the genome, fast. Science 283: 1867-1869.

Nelson, P.S., Hawkins, V., Schummer, M., Bumgarner, R., Ng, W.L., Ideker, T., Ferguson, C., and Hood, L. 1999. Negative selection: A method for obtaining low-abundance cDNAs using high-density cDNA clone arrays. Genet. Anal. 16: 209-215.

Nemoto, R. 1996. U.S. Patent Nos. 5,556,529 and 5,552,322.

Nie, R.S. and Zare, R.N. 1998. Optical detection of single molecules. Ann. Rev. Biophysics Biomol. Struc. 26: 567-596.

Nordstrom, T., Nourizad, K., Ronaghi, M., and Nyren, P. 2000. Method enabling pyrosequencing on double-stranded DNA. Anal. Biochem. 282: 186-193.

Northrup, M.A., Gonzalez, C., Hadley, D., Hills, R.F., Landre, P., Lehew, S., Saiki, R., Sninsky, J.J., Watson, R., and Watson, R. Jr. 1995. A MEMS-based miniature DNA analysis system. 8th Int. Conf. Solid-State Sensors Actuators Eurosensors IX. Digest of Technical Papers Found. Sensors \& Actuator Techol, Stockholm, Sweden; 1995. Vol. 1. 764-767.

Northrup, M.A., Hadley, D., Landre, P., Lehew, S., Richards, J., and Stratton, P. 1998. A miniature DNA-based analytical instrument based on micromachined silicon reaction chambers. Anal. Chem. 70: $918-922$.

O’Brien, K.M.,Wren, J., Dave, V.K., Bai, D., Anderson, R.D., Rayner, S., Evans, G.A., Dabiri, A.E., and Garner, H.R. 1998. ASTRAL, a hyperspectral imaging DNA sequencer. Rev. Sci. Instr. 69: 2141-2146.

Pang, H., Pavski, V., and Yeung, E.S. 1999. DNA sequencing using 96-capillary array electrophoresis. J. Biochem. Biophys. Methods 41: $121-132$.

Pease, A.C., Solas, D., Sullivan, E.J., Cronin, M.T., Holmes, C.P., and Fodor, S.P. 1994. Light-generated oligonucleotide arrays for rapid DNA sequence analysis. Proc. Natl. Acad. Sci. 91: 5022-5026.

Picoult-Newberg, L., Ideker, T., Pohl, M., Taylor, S., Donaldson, M., Nickerson, D., and Boyce-Jacino, M.T. 1999. Mining SNPs from EST databases. Genome Res. 9: 167-174.

Pollack, J.R., Perou, C.M., Alizadeh, A.A., M.B., Pergamenschikov, A., Williams, C.F., Jeffrey, S.S., Botstein, D., and Brown, P.O. 1999. Genome-wide analysis of DNA copy-number changes using 
cDNA microassays. Nat. Genet. 23: 41-46.

Radtkey, R., Feng, L., Muralhider, M., Duhon, M., Canter, D. DiPierro, D., Fallon, S., Tu, E., McElfresh, K., Nerenberg, M., et al. 2000. Rapid high fidelity analysis of simple sequence repeats on an electronically active DNA microchip. Nucleic Acids Res. 28: E17.

Rich, A. 1998. The rise of single-molecule DNA biochemistry. Proc. Natl. Acad. Sci. 95: 3999-4000.

Roepstorff, P. 2000. MALDI-TOF mass spectrometry in protein chemistry. EXS 88: 81-97.

Ronaghi, M., Gharizadeh, B., Nordstrom, T., Pourmand, N., Ekstrom, B., Uhlen, M., and Nyren, P. 1998a. Automated pyrosequencing in screening of a cDNA library. Microb. Comparat. Genomics 3: C-33.

Ronaghi, M., Uhlen, M., and Nyren, P. 1998b. A sequencing method based on real-time pyrophosphate. Science 281: 363-365.

Ronaghi, M., Nygren, M., Lundeberg, J., and Nyren, P. 1999. Analyses of secondary structures in DNA by pyrosequencing. Anal. Biochem. 267: 65-71.

Sasaki, N., Nagaoka, S., Itoh, M., Izawa, M., Konno, H., Carninci, P., Yoshiki, A., Kusakabe, M., Moriuchi, T., Muramatsu, M., et al. 1998. Characterization of gene expression in mouse blastocyst using single-pass sequencing of 3995 clones. Genomics 49: 167-179.

Sassi, A., Ricco, T., and Hooper, H. 2000. For electrophoresis, smaller is faster. Chemist Work 9: 44.

Scalf, M., Westphall, M.S., and Smith, L.M. 2000. Charge reduction electrospray mass spectrometry. Anal. Chem. 72: 52-60.

Schena, M. 1996. Genome analysis with gene expression microarrays. BioEssays 18: 427-431.

Schena, M., Shalon, D., Heller, R., Chai, A., Brown, P.O., and Davis, R.W. 1996. Parallel human genome analysis: Microarray-based expression monitoring of 1000 genes. Proc. Natl. Acad. Sci. 93: $10614-10619$.

Schena, M., Heller, R.A., Theriault, T.P., Konrad, K., Lachenmeier, E., and Davis, R.W. 1998. Microarrays: Biotechnology's discovery platform for functional genomics. Trends Biotechnol. 16: 301-306.

Scherer, J.R., Kheterpal, I., Radhakrishnan, A., Ja, W.W., and Mathies, R.A. 1999. Ultra-high throughput rotary capillary array electrophoresis scanner for fluorescent DNA sequencing and analysis. Electrophoresis 20: 1508-1517.

Schmalzing, D., Adourian, A., Koutny, L., Ziaugra, L., Matsudaira, P., adn Ehrlich, P. 1998. DNA sequencing on microfabricated electrophoretic devices. Anal. Chem. 70: 2303-2310.

Schmalzing, D., Koutny, L., Adourian, A., Belgrader, P., Matsudaira, P., and Ehrlich, D. 1997. DNA typing in thirty seconds with a microfabricated device. Proc. Natl. Acad. Sci. 94: 10273-10278.

Schmalzing, D., Tsao, N., Koutny, L., Chisholm, D., Srivastava, A., Adourian, A., Linton, L., McEwan, P., Matsudaira, P., and Ehrlich, D. 1999. Toward real-world sequencing by microdevice electrophoresis. Genome Res. 9: 853-858.

Sedlak, B.J. 1997. Gene chip technology ready to impact diagnostic markets. Genet. Eng. News 17.

Service, R.F. 2000. Getting a feel for genetic variations. Science 289: $27-28$.

-1998a. Coming soon: The pocket DNA sequencer. Science 282: 399-401.

1998b. Microchip arrays put DNA on the spot. Science 282: 396-399.

1998c. Picking up the pace of sequencing. Science 280: 995.

Shaler, T.A., Tan, Y., Wickham, J.N., Wu, K.J., and Becker, C.H. 1995. Analysis of enzymatic DNA sequencing reactions by matrix-assisted laser desorption/ionization time-of-flight mass spectrometry. Rapid Commun. Mass Spectrom. 9: 942-947.

Shalon, D., Smith, S.J., and Brown, P.O. 1996. A DNA microarray system for analyzing complex DNA samples using two-color fluorescent probe hybridization. Genome Res. 6: 639-645.

Shi, Y.N., Simpson, P.C., Scherer, J.R., Wexler, D., Skibola, C., Smith, M.T., and Mathies, R.A. 1999. Radial capillary array electrophoresis microplate and scanner for high-performance nucleic acid analysis. Anal. Chem. 71: 5354-5361.
Simpson, P.C., Roach, D., Woolley, A., Thorsen, T., Johnston, R., Sensabaugh, G.F., and Mathies, R.A. 1998a. High-throughput genetic analysis using microfabricated 96-sample capillary array electrophoresis microplates. Proc. Natl. Acad. Sci. 95: 2256-2261.

Simpson, P.C., Woolley, A.T., and Mathies, R.A. 1998b. Microfabrication technology for the production of capillary array electrophoresis chips. J. Biomed. Microdevices 1: 7-26.

Smith, A. and Watson, A. 1994. Parallel loading of sequencing gels. Sixth International Genome Sequencing and Analysis Conference, Hilton Head Island, SC.

Smith, A. and Watson, A. 1993. Sequencing gel loader. G.B. patent no: 9321650.5 .

- 1995. Sequencing gel loader. International patent no: PCT/GB94/02297.

Smith, L.M., Fung, S., Hunkapiller, M.W., Hunkapiller, T.J., and Hood, L. 1985. The synthesis of oligonucleotides containing an aliphatic amino group at the 5 ' terminus: Synthesis of fluorescent DNA primers for use in DNA sequence analysis. Nucleic Acids Res. 13: 2399-2412.

Smith, L.M., Sanders, J.Z., Kaiser, R.J., Hughes, P., Dodd, C., Connell, C.R., Heiner, C., Kent, S.B.H., and Hood, L.E. 1986. Fluorescence detection in automated DNA sequence analysis. Nature 321: $674-679$.

Soper, S.A., Ford, S.M., Xu, Y., Qi, S., McWhorter, S., Lassiter, S., Patterson, D., and Bruch, R.C. 1999. Nanoliter-scale sample preparation methods directly coupled to polymethylmethacrylate-based microchips and gel-filled capillaries for the analysis of oligonucleotides. J. Chromatogr. A 853: $107-120$.

Spurr, N., Darvasi, A., Terrett, J., and Jazwinska, L. 1999. New technologies and DNA resources for high throughput biology. $\mathrm{Br}$. Med. Bull. 55: 309-324.

Stegemann, J., Ventzki, R., Erfle, H., Schwager, C., Faulsich, K., Benes, V., Zimmermann, J., Li, Y., and Ansorge, W. 1999. 5000 bases in a single sequencing reaction on ARAKIS, towards 1 megabase DNA sequencer with automated loading. Microb. Comparat. Genomics 4: 97.

Struebe, E.T., Steward, J.Q., Chinwalla, A., Cook, L.L., Cook, M., Fronick, B., Miller, K., Mullen, M.K., O’Brien, D., Panussis, D.A., et al. 2000. Modification of a commercially available DNA sequencer to increase sample throughput. IEEE Eng. Med. Biol. Mag. 19: 101-106.

Suljak, S.W., Thompson, L.A., and Ewing, A.G. 1998. Electrophoretic separations in ultrathin channels using microelectrode array detection. In Micro total analysis systems '98 (ed. D.J. Harrison and A. van den Berg), pp. 113-116. Kluwer Academic Publishers, Boston, Massachusetts.

Swenson, R. 1999. Recent results of chemical synthesis on a microfluidic chip. Proceedings of Microchemical systems and Their Applications, ARO and DARPA, Reston, Virginia, June 16-18.

Swerdlow, H., Zhang, J.Z., Chen, D.Y., Harke, H.R., Grey, R., Wu, S., Fuller, C., and Dovichi, N.J. 1991. Three DNA sequencing methods using capillary gel electrophoresis and laser-induced fluorescence. Anal. Chem. 63: 2835-2841.

Swerdlow, H., Jones, B.J., and Wittwer, C.T. 1997. Fully automated DNA reaction and analysis in a fluidic capillary instrument. Anal. Chem. 69: 848-855.

Tan, H. and Yeung, E.S. 1998. Automation and integration of multiplexed on-line sample preparation with capillary electrophoresis for high-throughput DNA sequencing. Anal. Chem. 70: 4044-4053.

Tang, K., Fu, D.J., Julien, D., Braun, A., Cantor, C.R., and Koster, H. 1999. Chip-based genotyping by mass spectrometry. Proc. Natl. Acad. Sci. 96: 10016-10020.

Van Craenenbroeck, E. and Engelborghs, Y. 2000. Fluorescence correlation spectroscopy: molecular recognition at the single molecule level. J. Mol. Recognit. 13: 93-100.

Van den Berg, A., Olthuis, W., and Bergveld, P., eds. 2000. Micro total analysis systems 2000. Proceedings of the $\mu$ TAS 2000 Symposium, Enschede, The Netherlands, 14-18 May 2000. Kluwer 
Academic Publishers, Boston, Massachusetts.

Van Hal, N.L., Vorst, O., van Houwelingen, A.M., Kok, E.J., Peijnenburg, A., Aharoni, A., van Tunen, A.J. and Keijer, J. 2000. The application of DNA microarrays in gene expression analysis. J. Biotechnol. 78: 271-280.

Voss, H., Nentwich, U., Duthie, S., Wiemann, S., Benes, V., and Ansorge, W. 1997. Automated cycle sequencing with Taquenase: Protocols for internal labelling, dye primer and "doublex" simultaneous sequencing. Biotechnology 23: 312-318.

Wallingford, R.A. and Ewing, A.G. 1987. Capillary zone electrophoresis with electrochemical detection. Anal. Chem. 59: 1762-1766.

Walt, D.R. 2000. Techview: Molecular biolgy. Bead-based fiber-optic arrays. Science 287: 451-452.

Webster, J.R., Burns, M.A., Burke, D.T., and Mastrangelo, C.H. 1998. An inexpensive plastic technology for microfabricated capillary electrophoresis chips. In Micro total analysis systems '98 (ed. D.J. Harrison and A. van den Berg), pp. 249-252. Kluwer Academic Publishers, Boston, Massachusetts.

Wen, W.H., Bernstein, L., Lescallett, J., Beazer-Barclay, Y., Sullivan-Halley, J., White, M., and Press, M.F. 2000. Comparison of TP53 mutations identified by oligonucleotide microarray and conventional DNA sequence analysis. Cancer Res. 60: 2716-2722.

Wendl, M.C., Dear, S., Hodgson, D., and Hillier, L. 1998. Automated sequence preprocessing in a large-scale sequencing environment. Genome Res. 8: 975-984.

Westin, L., Xu, X., Miller, C., Wang, L., Edman, C.F., and Nerenberg, M. 2000. Anchored multiplex amplification on a microelectronic chip array. Nat. Biotechnol. 18: 199-204.

Wiest, D., Caren, M., Amorese, D., Bass, J., Bittner, M., Bruhn, L., Cattell, H., Chen, Y., DaQuino, L., Fisher, W., et al. 1999. Development of a cDNA microarray manufacturing platform utilizing a thermal ink jet deposition system. Microb. Comparat. Genomics 4: 120.

Wilding, P., Shoffner, M.A., and Kricka, L.J. 1994. PCR in a silicon microstructure. Clin. Chem. 40: 1815-1818.

Winzeler E.A., Schena, M., and Davis, R.W.1999. Fluorescence-based expression monitoring using microarrays. Methods Enzymol. 306: $3-18$.

Woolley, A.T., Guillemette, C., Li Cheung, C., Housman, D.E., and Lieber, C.M. 2000. Direct haplotyping of kilobase-size DNA using carbon nanotube probes. Nat. Biotechnol. 2000 18: 760-763.

Woolley, A.T. and Mathies, R.A. 1994. Ultra-high-speed DNA fragment separations using microfabricated capillary array electrophoresis chips. Proc. Natl. Acad. Sci. 91: 11348-11352.

Woolley, A.T., Hadley, D., Landre, P., deMello, A.J., Mathies, R.A., and Northrup, M.A. 1996. Functional integration of PCR amplification and capillary electrophoresis in a microfabricated DNA analysis device. Anal. Chem. 68: 4081-4086.

Woolley, A.T., Lao, K., Glazer, A.N., and Mathies, R.A. 1998. Capillary electrophoresis chips with integrated electrochemical detection. Anal. Chem. 70: 684-688.

Xiong, Y., Park, S.-R., and Swerdlow, H. 1998. Base stacking: $\mathrm{pH}$-mediated on-column sample-concentration for capillary DNA sequencing. Anal. Chem. 70: 3605-3611.

Yager, T.D., Baron, L., Batra, R., Bouevitch, A., Chan, D., Chan, K., Darasch, S., Gilchrist, R., Izmailov, A., Lacroix, J.M., et al. 1999. High performance DNA sequencing, and the detection of mutations and polymorphisms, on the Clipper sequencer. Electrophoresis 20: 1280-1300.

Yates, J.R. 3rd. 2000. Mass spectrometry. From genomics to proteomics. Trends Genet. 16: 5-8.

Yershov, G., Barsky, V., Belgovskiy, A., Kirillov, E., Kreindlin, E., Ivanov, I., Parinov, S., Guschin, D., Drobishev, A., Dubiley, S., and Mirzabekov, A. 1996. DNA analysis and diagnostics on oligonucleotide microchips. Proc. Natl. Acad. Sci. 93: 4913-4918.

Yeung, E.S. 1999. Study of single cells by using capillary electrophoresis and native fluorescence detection. J. Chromatogr. 830: $243-262$.

Yin, Z., Severin, J., Giddings, M.C., Huang, W., Westphall, M.S., and Smith, L.M. 1996. Automatic matrix determination in four dye fluorescence-based DNA sequencing. Electrophoresis 17: $1143-1150$.

Zhang, J., Voss, K.O., Shaw, D.F., Roos, K.P., Lewis, D.F., Yan, J., Jiang, R., Ren, H., Hou, J.Y., Fang, Y., Puyang, X., Ahmadzadeh, H., and Dovichi, N.J. 1999. A multiple-capillary electrophoresis system for small-scale DNA sequencing and analysis. Nucleic Acids Res 27: e36.

Zhang, J.Z., Fang, Y., Hou, J.Y., Ren, H.J., Jiang, R., Roos, P., and Dovichi, N.J. 1995. Use of non-cross-linked polyacrylamide for four-color DNA sequencing by capillary electrophoresis separation of fragments up to 640 bases in length in two hours. Anal. Chem. 67: 4589-4593.

Zhang, M.Q. 1999. Large-scale gene expression data analysis: A new challenge to computational biologists. Genome Res. 9: 681-688.

Zhang, N., Tan, H., and Yeung, E.S. 1999. Automated and integrated system for high-throughput DNA genotyping directly from blood. Anal. Chem. 71: 1138-1145. 


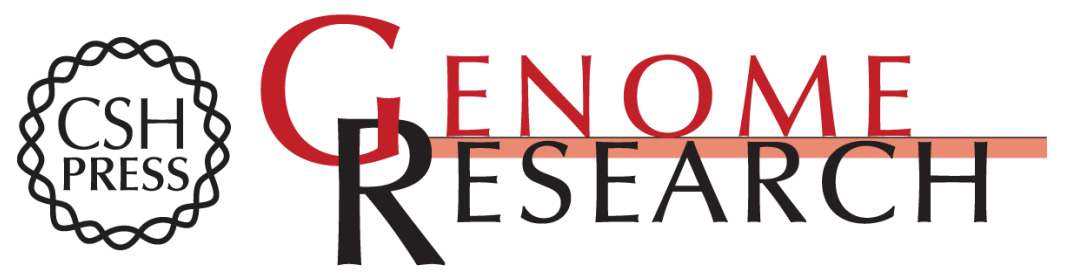

\section{Automation for Genomics, Part Two: Sequencers, Microarrays, and Future Trends}

Deirdre Meldrum

Genome Res. 2000 10: 1288-1303

Access the most recent version at doi:10.1101/gr.157400

References This article cites 163 articles, 39 of which can be accessed free at:

http://genome.cshlp.org/content/10/9/1288.full.html\#ref-list-1

\section{License}

Email Alerting Receive free email alerts when new articles cite this article - sign up in the box at the Service top right corner of the article or click here.

\section{Affordable, Accurate Sequencing.}

To subscribe to Genome Research go to: https://genome.cshlp.org/subscriptions 